\title{
Tag SNPs in complement receptor-1 contribute to the susceptibility to non-small cell lung cancer
}

\author{
Xinfeng Yu ${ }^{1,2}$, Juan Rao ${ }^{2}$, Jia Lin², Zhi Zhang ${ }^{3}$, Lei $\mathrm{CaO}^{2}$ and Xuemei Zhang ${ }^{2^{*}}$
}

\begin{abstract}
Background: Complement receptor 1 (CR1), the receptor for C3b/C4b complement peptides, plays a crucial role in carcinogenesis. However, the association of genetic variants of CR1 with susceptibility to lung cancer remains unexplored.

Methods: This case-control study included 470 non-small cell lung cancer (NSCLC) patients and 470 cancer-free controls. Based on the Chinese population data from HapMap database, we used Haploview 4.2 program to select candidate tag SNPs. Odds ratios (ORs) and 95\% confidence intervals (Cls) were computed by logistic regression to evaluate the association of each tag SNP with NSCLC.

Results: Multivariate regression analysis indicated that the rs7525160 CC genotype was associated with an increased risk of developing NSCLC (OR $=1.52,95 \% \mathrm{Cl}=1.02-2.28 ; P=0.028)$ compared with the GG genotype. When stratified by smoking status, the risk of NSCLC was associated with the rs $7525160 \mathrm{C}$ allele carriers in smokers with OR (95\% Cl) of 1.72 (1.15-2.79), but not in non-smokers with OR (95\% Cl) of 1.15 (0.81-1.65). When the interaction between smoking status and rs $7525160 \mathrm{G}>\mathrm{C}$ variant was analyzed with cumulative smoking dose (pack-year). Similarly, GC or CC genotype carriers have increased risk of NSCLC among heavy smokers (pack-year $\geq 25$ ) with OR (95\% Cl) of 2.01 (1.26-3.20), but not among light smokers (pack-year <25) with OR (95\% Cl) of 1.32 (0.81-2.16).

Conclusion: CR1 rs7525160 G > C polymorphism was associated with an increased risk of developing NSCLC in Chinese population. The association displays a manner of gene-environmental interaction between CR1 rs7525160 tagSNP and smoking status.
\end{abstract}

Keywords: CR1, Polymorphism, Tag SNPs, Lung cancer

\section{Background}

The complement system plays a critical role in the process of carcinogenesis. Despite of significant research, controversial viewpoints remain on the exact relationship of complement system with cancer. Classically, the complement system fights against cancer by exerting the effects of immunosurveillance in the immunologic microenvironment of tumors [1]. Recently it was found that complement may contribute to tumor growth by a wide variety of mechanisms including dysregulation of mitogenic signaling pathways, sustained cellular proliferation, angiogenesis, insensitivity to apoptosis, invasion and migration, and escape from complement cytotoxicity [2]. This suggested complement, just like a double-edged sword, plays a dual

\footnotetext{
* Correspondence: jyxuemei@gmail.com

2Department of Molecular Genetics, College of Life Science, Hebei United University, Tangshan 063000, China

Full list of author information is available at the end of the article
}

role in carcinogenesis. In particular, component $\mathrm{C} 3$ and its receptors have been demonstrated to be a key link between innate and adaptive immunity [3].

Complement receptor type 1 (CR1, CD35) is a multifunctional polymorphic glycoprotein which binds to C3b fragment of C3 and to C4b with lower affinity $[4,5]$. CR1 belongs to the regulators of complement activation (RCA) family of proteins and is expressed in a wide spectrum of cells and involved in T-cell and B-cell mediated immune regulation [6,7]. CR1 also modulates the complement cascade activation by preventing formation of classical and alternative pathway convertases and by acting as a cofactor for factor I mediated inactivation of $\mathrm{C} 3 \mathrm{~b}$ and $\mathrm{C} 4 \mathrm{~b}$ $[8,9]$. It has been demonstrated that chronic inflammation can predispose to cancer development and spread [10], as a fundamental component of innate immunity, the complement cascade consists of potential proinflammatory 
molecules especially C3 and C5. Moreover, complement activation and abnormal expression in tumor tissues has been demonstrated [11]. Considering the important role of CR1 in complement activation, innate immunity and chronic inflammation, CR1 has emerged as a molecule of immense interest in gaining insight into the susceptibility to cancer.

CR1 gene is located on the Chromosome 1 at the locus $1 q 32$ [12]. Various polymorphisms have been studied including the intronic and exonic density polymorphism for their ability to alter the density of erythrocyte CR1 on the cell membranes [13-15]. There are also the molecular weight variants due to insertion-deletion polymorphisms [16]. Up to now, there have been very few studies on the association of genetic variants of CR1 with susceptibility to autoimmune and inflammatory diseases. It has been proposed that genetic variant at CR1 gene (rs6656401) might influence the susceptibility to late-onset Alzheimer's disease [17]. CR1 expression in Peripheral Blood Mononuclear Cells (PBMCs) may be a new biomarker for prognosis of nasopharyngeal carcinoma and a potential therapeutic target [18]. Recently, it has been indicated that CR1 A3650G (His1208Arg) polymorphism plays a critical role in conferring genetic susceptibility to gallbladder cancer in north Indian population [19]. However, the association of genetic variants of $C R 1$ with risk of lung cancer remains unexplored.

Worldwide, lung cancer is the most common cancer in terms of both incidence and mortality [20]. NSCLC is the most common subtype of lung cancer and less aggressive and metastic than SCLC. Although cigarette smoking is the predominant risk factor for lung cancer, inherited genetic characteristics are presumed to account in part for this interindividual variation in lung cancer susceptibility. Recently, several genome-wide association studies have demonstrated the common genetic variations associated with susceptibility to lung cancer [21-24]. Given the involvement of the complement system in coordinating innate immunity and inflammatory response [25], further examination of the potential association between genetic variation of $C R 1$ genes and lung cancer is warranted.

In the current study, we conducted a case-control study to investigate the association of tag SNPs in CR1 gene with the risk of NSCLC and effect of the interaction of gene-environment on the risk of NSCLC.

\section{Results}

\section{Subject characteristics}

The frequency distributions of select characteristics in cases and control subjects were shown in Table 1. The mean age $( \pm S D)$ was $59.6 \pm 10.5$ years for the cancer patients and $57.2 \pm 13.3$ years for the controls. No significant
Table 1 Distributions of select characteristics in cases and control subjects

\begin{tabular}{|c|c|c|c|c|c|}
\hline \multirow[t]{2}{*}{ Variables } & \multicolumn{2}{|c|}{ Cases $(n=470)$} & \multicolumn{2}{|c|}{ Controls $(n=470)$} & \multirow[b]{2}{*}{$P^{a}$} \\
\hline & No & (\%) & No & (\%) & \\
\hline Sex & & & & & 0.832 \\
\hline Male & 324 & 68.9 & 328 & 69.8 & \\
\hline Female & 146 & 31.1 & 142 & 30.2 & \\
\hline Age & & & & & 0.470 \\
\hline$<50$ & 84 & 17.9 & 96 & 20.4 & \\
\hline $50-59$ & 177 & 37.7 & 187 & 39.8 & \\
\hline $60-69$ & 129 & 27.4 & 111 & 23.6 & \\
\hline$\geq 70$ & 80 & 17.0 & 76 & 16.2 & \\
\hline Smoking status & & & & & 0.321 \\
\hline Non-smoker & 265 & 56.4 & 281 & 59.8 & \\
\hline Smoker & 205 & 43.6 & 189 & 40.2 & \\
\hline Pack-year smoked & & & & & 0.001 \\
\hline$<25$ & 75 & 36.6 & 96 & 50.8 & \\
\hline$\geq 25$ & 130 & 63.4 & 93 & 49.2 & \\
\hline
\end{tabular}

${ }^{\mathrm{a}}$ Two-sided $\mathrm{x}^{2}$ test.

difference was found in the mean age between cases and controls $(P=0.470)$. There was no significant difference in proportion of sex and smoking status between cases and controls ( $P=0.832$ and $P=0.321$, respectively). However, there was significant difference between cases and controls when compared by pack-year smoked $(P=0.001)$. The heavy smokers ( $\geq 25$ pack-year) accounted for $61.5 \%$ in cases but only $45.5 \%$ in controls, which suggested that cigarette smoking was a prominent contributor to the risk of lung cancer. Of the 470 case patients, 178 (37.9\%) were diagnosed as adenocarcinoma, $238(50.6 \%)$ as squamous cell carcinoma, and 100 (\%) as other types, including large cell carcinoma $(n=49)$ and mixed cell carcinoma $(n=5)$.

\section{Association of CR1 tag SNP with NSCLC risk}

Total 13 selected tag SNPs of CR1 in HapMap database among Chinese population were analyzed. Except for rs9429782 polymorphism, the genotype distributions of other SNPs in controls were consistent to HardyWeinberg equilibrium. Therefore, we excluded the rs9429782 from further analysis. In order to screen the genetic variants that confer the susceptibility to lung cancer, 12 candidate tagSNPs were genotyped in a casecontrol study consisting of 470 lung cancer patients and 470 cancer-free controls as shown in Table 2. Importantly, genotype frequency of one intronic SNP (rs7525160 G > C) in cases was found to be significantly different from those of controls $\left(x^{2}=6.339, P=0.042\right)$. Further multivariate regression model with adjustment for age, gender, and smoking status was used to assess the association between rs7525160 $\mathrm{G}>\mathrm{C}$ polymorphism 
Table 2 Genotype frequencies of CRI among cases and controls and their association with non-small cell lung cancers

\begin{tabular}{|c|c|c|c|c|c|c|}
\hline \multirow{2}{*}{$\begin{array}{c}\text { CRI } \\
\text { Genotypes }\end{array}$} & \multicolumn{2}{|c|}{$\begin{array}{l}\text { Controls } \\
(n=470)\end{array}$} & \multicolumn{2}{|c|}{$\begin{array}{c}\text { Cases } \\
(n=470)\end{array}$} & \multirow[t]{2}{*}{ OR $(95 \% C l)^{*}$} & \multirow[t]{2}{*}{$P$} \\
\hline & No & $(\%)$ & No & $(\%)$ & & \\
\hline \multicolumn{7}{|l|}{ rs7525160 } \\
\hline GG & 176 & 37.5 & 139 & 29.6 & 1.00 (ref.) & \\
\hline$C G$ & 228 & 48.5 & 256 & 54.5 & $1.38(1.04-1.85)$ & 0.041 \\
\hline$C C$ & 66 & 14.0 & 75 & 15.9 & $1.52(1.02-2.28)$ & 0.028 \\
\hline
\end{tabular}

rs3886100

$\begin{array}{lllllll}\text { GG } & 117 & 24.9 & 105 & 22.4 & 1.00 \text { (ref.) } & \\ \text { AG } & 223 & 47.4 & 253 & 53.8 & 1.33(0.97-1.81) & 0.078 \\ \text { AA } & 130 & 27.7 & 112 & 23.8 & 1.06(0.73-1.54) & 0.755\end{array}$

rs11118167

$\begin{array}{lllllll}\pi & 348 & 74.1 & 353 & 75.1 & 1.00 \text { (ref.) } & \\ \mathrm{CT} & 111 & 23.6 & 102 & 21.7 & 0.89(0.65-1.21) & 0.457 \\ \mathrm{CC} & 11 & 2.3 & 15 & 3.2 & 1.35(0.61-3.01) & 0.461\end{array}$

rs9429782

$\begin{array}{llllll}\text { GG } & 250 & 53.2 & 261 & 55.5 & 1.00 \text { (ref.) }\end{array}$

$\begin{array}{llllll}\text { GT } & 220 & 46.8 & 209 & 44.5 & 0.89(0.69-1.1\end{array}$

rs10494885

$\begin{array}{llllll}\text { CC } & 178 & 37.9 & 164 & 34.9 & 1.00 \text { (ref.) }\end{array}$

$\begin{array}{lllllll}\text { CT } & 224 & 47.6 & 232 & 49.4 & 1.11 & (0.83-1.47)\end{array}$

$\Pi \mathrm{T}$

rs 7542544

$\begin{array}{llllll}\text { CC } & 128 & 27.2 & 108 & 23.0 & 1.00 \text { (ref.) }\end{array}$

$\begin{array}{lllllll}\text { AC } & 223 & 47.5 & 252 & 53.6 & 1.21 & (0.88-1.67)\end{array}$

$\begin{array}{llllll}\text { AA } & 119 & 25.3 & 110 & 23.4 & 0.90\end{array}$

0.239

0.897

rs6691117

$\begin{array}{llllll}\text { AA } & 324 & 68.9 & 327 & 69.6 & 1.00 \text { (ref.) }\end{array}$

$\begin{array}{llllll}\text { AG } & 131 & 27.9 & 128 & 27.2 & 0.98 \\ (0.73-1.31)\end{array}$

$\begin{array}{llllll}\text { GG } & 15 & 3.2 & 15 & 3.2 & 0.96(0.46-2.02)\end{array}$

0.888

0.923

rs6656401

$\begin{array}{llllll}\text { GG } & 436 & 92.8 & 447 & 95.1 & 1.00 \text { (ref.) }\end{array}$

$\begin{array}{llllll}\text { AG } & 34 & 7.2 & 23 & 4.9 & 0.68(0.39-1.18)\end{array}$

$\begin{array}{llllll}\text { AA } & 0 & 0.0 & 0 & 0.0 & N C^{\S}\end{array}$

rs2296160

$\begin{array}{llllll}\text { CC } & 185 & 39.4 & 194 & 41.3 & 1.00 \text { (ref.) }\end{array}$

$\begin{array}{llllll}\text { CT } & 226 & 48.1 & 220 & 46.8 & 0.91(0.69-1.21)\end{array}$

$\begin{array}{llllll}\pi & 59 & 12.5 & 56 & 11.9 & 0.90\end{array}$

0.521

0.606

rs9429942

$\begin{array}{llllll}\Pi T & 452 & 96.2 & 457 & 97.2 & 1.00 \text { (ref.) } \\ \mathrm{CT} & 18 & 3.8 & 13 & 2.8 & 0.77(0.37-1.61) \\ \mathrm{CC} & 0 & 0.0 & 0 & 0.0 & N C^{\S}\end{array}$

Table 2 Genotype frequencies of CRI among cases and controls and their association with non-small cell lung cancers (Continued)

\begin{tabular}{|c|c|c|c|c|c|c|}
\hline \multicolumn{7}{|c|}{ rs4844600 } \\
\hline GG & 171 & 36.4 & 179 & 38.1 & 1.00 (ref.) & \\
\hline$A G$ & 230 & 48.9 & 228 & 48.5 & $0.92(0.70-1.22)$ & 0.571 \\
\hline AA & 69 & 14.7 & 63 & 13.4 & $0.87(0.58-1.31)$ & 0.513 \\
\hline \multicolumn{7}{|c|}{ rs3818361 } \\
\hline CC & 187 & 39.8 & 188 & 40.0 & 1.00 (ref.) & \\
\hline CT & 224 & 47.7 & 224 & 47.7 & $0.98(0.74-1.29)$ & 0.868 \\
\hline$\pi$ & 59 & 12.5 & 58 & 12.3 & $0.96(0.63-1.46)$ & 0.848 \\
\hline \multicolumn{7}{|c|}{ rs17048010 } \\
\hline$\pi$ & 301 & 64.0 & 286 & 60.8 & 1.00 (ref.) & \\
\hline$C T$ & 154 & 32.8 & 164 & 34.9 & $1.09(0.82-1.43)$ & 0.556 \\
\hline CC & 15 & 3.2 & 20 & 4.3 & $1.40(0.70-2.79)$ & 0.343 \\
\hline
\end{tabular}

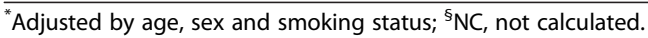

and the risk of NSCLC. The results indicated that the rs7525160 CC genotype was associated with an increased risk of developing NSCLC with OR (95\% CI) of 1.52 (1.02-2.28) compared with the GG genotype. Other tagSNPs of $C R 1$ were not significantly associated with the risk of NSCLC in our study population $(P>0.05)$.

Generalized Multifactor Dimensionality Reduction (GMDR) was used to evaluate gene-gene interaction. The summary of gene-gene interaction models is listed in Table 3. The SNP rs7525160 in CR1 had the highest testing balanced accuracy among 12 SNPs. The threeway interaction model among rs4844600, rs10494885 and rs7525160 showed high testing balance accuracy and cross validation consistency, but the testing balanced accuracy was lower than the two-way gene-gene interaction in NSCLC. For each model, the interaction was not significant $(P>0.05)$.

\section{Interaction of CR1 SNP with smoking}

Cigarette smoking is a well-known risk for lung cancer, so stratification by smoking status was performed to investigate the association of rs7525160 $\mathrm{G}>\mathrm{C}$ variant with the risk of NSCLC. As shown in Table 4, the risk of NSCLC was associated with the rs7525160 C allele carriers in smokers with OR $(95 \% \mathrm{CI})$ of 1.72 (1.15-2.59), but not in non-smokers with OR (95\% CI) of 1.15 (0.81-1.65), suggesting that the CR1 rs7525160 $\mathrm{G}>\mathrm{C}$ polymorphism is a smoking-modifying risk factor for susceptibility to NSCLC. When the interaction between smoking status and rs7525160 G > C variant was analyzed with cumulative smoking dose (pack-year), consistently, GC or CC genotype carriers have increased risk of NSCLC among heavy smokers (pack-year $\geq 25)$ with OR $(95 \% \mathrm{CI})$ of 2.01 (1.26-3.20), but not among light smokers (pack-year $<25$ ) 
Table 3 Summary of MDR gene-gene interaction results

\begin{tabular}{lcccc}
\hline Models & $\begin{array}{c}\text { Training } \\
\text { bal. acc. (\%) }\end{array}$ & $\begin{array}{c}\text { Testing bal. } \\
\text { acc. (\%) }\end{array}$ & $\begin{array}{c}\boldsymbol{P} \\
\text { value }\end{array}$ & $\begin{array}{c}\text { Cross-validation } \\
\text { consistency }\end{array}$ \\
\hline rs7525160 & 54.03 & 50.53 & 0.828 & $7 / 10$ \\
rs4844600, & 55.45 & 49.32 & 0.989 & $3 / 10$ \\
rs10494885 & & & & \\
rs4844600, & 57.60 & 48.48 & 0.623 & $6 / 10$ \\
rs10494885, & & & & \\
rs7525160 & & & & \\
\hline
\end{tabular}

with OR $(95 \% \mathrm{CI})$ of 1.32 (0.81-2.16). The $P$ value for heterogeneity of the stratification analysis by smoking status is 0.015 . However, the $\mathrm{P}$ value for interaction between rs7525160 polymorphism and smoking is 0.172 and the power for the interaction is 0.49 .

\section{Discussion}

The chronic airway inflammation and dysfunctional immune system might promote pulmonary carcinogenesis. Implicated in the immune and inflammatory responses, the complement cascade plays a pivotal role in the development of cancer. Thus, it is likely that the genetic variants of CR1 in the complement system confer the susceptibility to lung cancer. In this study, we have for the first time demonstrated that one intronic SNP (rs7525160 G > C) out of 13 tag SNPs of CR1 was associated with the risk of NSCLC in Chinese population. Notably, the rs7525160 CC genotype was associated with an increased risk of developing NSCLC (OR $=1.52$, 95\% $\mathrm{CI}=1.02-2.28 ; P=0.028$ ) compared with the GG genotype. MDR analysis also showed that there was no gene-gene interaction among 12 tag SNPs in CR1 gene. Moreover, the risk of NSCLC was associated with the rs7525160 C allele carriers in smokers with OR (95\% CI) of 1.72 (1.15-2.59), but not in non-smokers with OR (95\% CI) of 1.15 (0.81-1.65), indicating this SNP is a smokingmodifying risk factor for susceptibility to NSCLC. To the best of our knowledge, this study shed new insight into the interplay of genetic variation of CR1 with lung cancer risk. More importantly, it highlights the potential gene-environmental interaction influences the susceptibility to lung cancer.
The complement system has been proposed to get involved in innate immunity with the ability to "complement" antibody-mediated elimination of immune complex and foreign pathogens [26]. Upon complement activation, the biologically active peptides C5a and C3a elicit a lot of pro-inflammatory effects and could be closely associated with tumorigenesis [27]. Complement proteins play a dual role in the tumor microenvironment. On one hand, they exert a defensive effect against tumor through complement or antibody-dependent cytotoxicity $[1,28]$. On the other hand, they may escape from immunosurveillance and facilitate carcinogenesis [2]. Specifically, a number of experimental evidence has suggested an association between complement activation and tumor growth $[29,30]$, which provides a strong biologically link between the abnormal expression and activity of complement cascade and carcinogenesis.

Till now, a few studies have been carried out to demonstrate the association of genetic variants in complement proteins with susceptibility to cancer. A significant association of CR2 SNP (rs3813946) with the development of nasopharyngeal carcinoma was indicated in Cantonese population [31], and the genetic variations of complement system genes C5 and C9 plays a potential role in susceptibility to non-Hodgkin lymphoma (NHL) [32]. Recently, it has been shown that complement factor $\mathrm{H} \mathrm{Y} 402 \mathrm{H}$ polymorphism interact with cigarette smoking to confer the susceptibility to lung cancer [33]. Furthermore, it has been indicated that CR1 A3650G (His1208Arg) polymorphism plays a critical role in conferring genetic susceptibility to gallbladder cancer in north Indian population [19]. However, whether the genetic variants of $C R 1$ are related to the risk of lung cancer remains unknown. In this case-control study, we found an intronic SNP (rs7525160 G > C) with CC genotype was significantly associated with an increased risk of NSCLC. Consistently, our results were in accordance with the study that genetic polymorphisms in innate immunity genes may play a role in the carcinogenesis of lung cancer [34]. It is likely that some genetic variations in strong link disequilibrium with this intronic SNP (rs7525160 G > C) are functional, which provides a new insight into the hallmarks in susceptibility to lung cancer and further

Table 4 Risk of CR1 genotypes with NSCLC by smoking status

\begin{tabular}{|c|c|c|c|c|c|c|}
\hline \multirow{2}{*}{$\begin{array}{l}\text { Smoking } \\
\text { status }\end{array}$} & \multicolumn{6}{|c|}{ CR1 genotype } \\
\hline & $\mathrm{GG}^{*}$ & OR $(95 \% \mathrm{Cl})^{\S}$ & $P$ value & $\mathrm{CG}+\mathrm{CC}^{*}$ & OR $(95 \% \mathrm{Cl})^{\S}$ & $P$ value \\
\hline Non-smoker & $84 / 99$ & 1.00 (reference) & & 181/182 & $1.15(0.81-1.65)$ & 0.440 \\
\hline Smoker & $55 / 77$ & $0.86(0.54-1.38)$ & 0.528 & $150 / 112$ & $1.72(1.15-2.59)$ & 0.009 \\
\hline$<25$ pack-years & $19 / 41$ & $0.59(0.31-1.10)$ & 0.099 & $56 / 55$ & $1.32(0.81-2.61)$ & 0.266 \\
\hline$\geq 25$ pack-years & $36 / 36$ & $1.18(0.67-2.08)$ & 0.562 & $94 / 57$ & $2.01(1.26-3.20)$ & 0.003 \\
\hline
\end{tabular}

"Number of cases/number of controls.

${ }^{5}$ Data were calculated by logistic regression and adjusted for age and gender. 
functional experiments are warranted to address the proposal.

Functionally, human CR1 exists on the surface of almost all peripheral blood cells and plays a key role in immune complex clearance and complement inhibition at the cell surface by binding to activated products $\mathrm{C} 3 \mathrm{~b}$ and C4b $[4,35]$. CR1 also possesses cofactor activity for the serum protease factor I and is thus involved in the generation of further fragments of $\mathrm{C} 3 / 4 \mathrm{~b}$ with the activation of complement cascade and the cellular immune response [4]. In our study, the association of $C R 1$ polymorphism with lung cancer is biologically plausible in that the intronic polymorphism could affect the density of CR1 molecules on the cell surface, thereby contributing to autoimmune disorders and neoplasm.

Tobacco smoking is an established risk factor for susceptibility to lung cancer. However, not all people who suffer from lung cancer are smokers. Lung cancer in non-smokers can be induced by second hand smoke, air pollutants and diesel exhaust [36-39]. Our present data showed significant difference of pack-year smoked, but not smoking status between NSCLC cases and controls, which suggested the important role of other environmental factors in the development of NSCLC. Tobacco could induce chronic and sustained inflammation in lung microenvironment, contributing to pulmonary carcinogenesis in smokers [40]. Support also comes from the epidemiologic data regarding inflammation and lung cancer [41]. CR1, an important molecule implicated in immunity and inflammation, could protect the host from invasion of exogenous chemicals derived from cigarette smoking. Genetic variant of CR1 could alter gene function and result in deregulation of the inflammatory and immune responses, thereby, modulating the susceptibility to lung cancer. More importantly, we observed a potential interaction of this SNP (rs7525160 G > C) with smoking status, suggesting the gene-environmental interaction plays a prominent role in the susceptibility to lung cancer. Our present study has its limitation. Our patients may not be representative of total NSCLC patients at large because they were recruited from only one hospital. In addition, due to the relatively small sample size, further case-control studies are still needed to replicate and extend our findings.

\section{Conclusion}

We conducted a case-control study in Chinese subjects and found an intronic SNP (rs7525160 G > C) of CR1 was significantly associated with lung cancer risk. To the best of our knowledge, this study provides the first evidence that genetic variant of CR1 (rs7525160 G > C) was a smoking-modifying contributor to the development of lung cancer.

\section{Methods}

\section{Study subjects}

This case-control study consisted of 470 patients with histopathologically confirmed NSCLC and 470 cancerfree controls. All subjects were genetic unrelated ethnic Han Chinese. Patients were recruited between January 2008 and December 2012 at Tangshan Gongren Hospital (Tangshan, China). There were no age, gender or stage restrictions, however, patients with previous malignancy or metastasized cancer from other organs were excluded. The response rate for patients was $94 \%$. The controls were randomly selected from a pool of a cancer-free population from a nutritional survey conducted in the same region. The selection criteria for control subjects included: i) no individual history of cancer; ii) frequency

Table 5 Primers used in this study

\begin{tabular}{|c|c|c|c|c|}
\hline SNP_ID & leles & CR primer sequences & d PCP $n$ & s \\
\hline rs7525160 & $\mathrm{G} / \mathrm{C}$ & $\Gamma$ & A & $T$ \\
\hline 100 & $\mathrm{~A}$ & CCTCAGATCCTCAAAATC & ACGTTGGATGTGAGCTGTITCAGCCAAGAG & CTTAG \\
\hline s11118167 & $\mathrm{T} / \mathrm{C}$ & C & C & CAAT \\
\hline rs9429782 & $\mathrm{G} / \mathrm{T}$ & ACGTTGGATGACACGCGGGATCCATCGGAA & ACGTTGGATGAACGAGTTTCGCTGGCAGAG & GGTGCAGC \\
\hline rs10494885 & 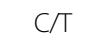 & C & ACGTTGGATGCCAGCCAACTGACCTITATG & $A C$ \\
\hline rs7542544 & $\mathrm{C} / \mathrm{A}$ & ACGTTGGATGGCTAAGAC & ACGTTGGATGAAC & CCATGA \\
\hline 7 & $A / G$ & $\mathrm{ACC}$ & A & CCGC \\
\hline rs6656401 & $\mathrm{G} / \mathrm{A}$ & ACGTTGGATGAAAGGACACACACAGAGGAG & ACGTTGGATGCGTTGATGTTCCTTGGCTTG & СTCTGTCTCCATC \\
\hline rs. & $\mathrm{C} / \mathrm{T}$ & $\mathrm{ACC}$ & ACG & CGTGC \\
\hline rs9429942 & $\mathrm{T} / \mathrm{C}$ & ACGTTGGATGTACATGTGCACAACGTGCAG & ACGTTGGATGAAC & GGGAACGTCGC \\
\hline 154844000 & 管 & 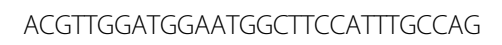 & ACGTTGGATGGGGCGGCATTCATAGTTCAG & CLCAAIG \\
\hline rs3818361 & $C / T$ & ACGTTGGATGTGGAAAGGACAGTTCCAGAG & ACGTTGGATGTITTAAGCCCTCTGGTAAGC & TAATCCCTCTGGTAAGCATAAGATA \\
\hline 17048010 & $\mathrm{~T} / \mathrm{C}$ & ACGTTGGATGTTTCAAGGCTGCTCCTTGTT & CGTTGGATGCCCAGTCTATGGAGTTTCTG & AGACTGAGACAGTTGGT \\
\hline
\end{tabular}


matched to cases according to gender, age ( \pm 5 years); iii) the residential region; and iv) the time period for blood sample collection. At recruitment, informed consent was obtained from each subject, and each participant was then interviewed to collect detailed information on demographic characteristics. This study was approved by the institutional review board of Hebei United University.

\section{Tag SNPs selection and genotyping}

Based on the Chinese population data from HapMap database, we used Haploview 4.2 program to select candidate tag SNPs with an $r^{2}$ threshold of 0.80 and minor allele frequency (MAF) greater than 1\%. Furthermore, we also added two potential functional polymorphisms, rs9429942 and rs6691117 [42,43]. Therefore, we included 13 SNPs in our study, which represents common genetic variants in Chinese population.

Genotyping was performed at Bomiao Tech (Beijing, China) using iPlex Gold Genotyping Asssy and Sequenom MassArray (Sequenom, San Diego, CA, USA). Sequenom's MassArray Designer was used to design PCR and extension primers for each SNP. Primer information for selected tag SNPs was listed in Table 5.

\section{Statistical analysis}

We used Chi-square test to examine the differences in the distributions of demographic characteristics, and genotype frequencies between cases and controls. The NSCLC risk associated with CR1 tag SNPs was estimated as odds ratios (OR) and 95\% confidence intervals (CI) computed by logistic regression model adjusted for age, gender, and smoking status where it was appropriate. Smokers were considered current smokers if they smoked up to 1 year before the date of cancer diagnosis for NSCLC patients or before the date of the interview for controls. The number of pack-years smoked was determined as an indication of cumulative cigarette-dose level $[$ pack-year $=($ cigarettes per day/20 $) \times($ years smoked $)]$. Light and heavy smokers were categorized by using the 50th percentile pack-year value of the controls as the cut points (i.e., $\leq 25$ and $>25$ pack-years). All statistical tests were 2 sided with $P<0.05$ as the significant level. Statistical analyses were done using SPSS (version 16.0, SPSS Inc, Chicago, IL). Gene-gene and gene-smoking interactions were analyzed by open-resource GMDR software package (version 0.9) and Quanto (http://www.hydra.usc.edu/gxe) $[44,45]$.

\section{Abbreviations}

CR1: Complement receptor 1; OR: Odds ratio; Cl: Confidence interval; SNP: Single nucleotide polymorphism.

\section{Competing interests}

The authors declare no competing financial interest.

\section{Authors' contributions}

$X Y$ drafted the article. XY and JR conducted genotyping of CR1. JL, ZZ and LC collected clinical data and analyzed the data. XZ contributed the research plan and approved the data. All authors read and approved the final manuscript.

\section{Acknowledgements}

This work was supported by the National Natural Sciences Foundation of China to XZ (no. 81101483), Program for New Century Excellent Talents in University to XZ (NCET-11-0933), Science Fund for Distinguished Young Scholars of Hebei Scientific Committee to XZ (H2012401022) and Foundation for the Author of National Excellent Doctoral Dissertation of PR China (FANEDD) (no. 201274).

\section{Author details}

'Department of Pharmacology, School of Chemical Biology and Pharmaceutical Sciences, Capital Medical University, Beijing, China ${ }^{2}$ Department of Molecular Genetics, College of Life Science, Hebei United University, Tangshan 063000, China. ${ }^{3}$ Department of Chemotherapy and Radiotherapy of Cancer, Tangshan Gongren Hospital, Tangshan, China.

Received: 12 September 2013 Accepted: 24 February 2014 Published: 12 March 2014

\section{References}

1. Gelderman KA, Tomlinson S, Ross GD, Gorter A: Complement function in mAb-mediated cancer immunotherapy. Trends Immunol 2004, 25:158-164.

2. Rutkowski MJ, Sughrue ME, Kane AJ, Mills SA, Parsa AT: Cancer and the complement cascade. Mol Cancer Res 2010, 8:1453-1465.

3. Liu D, Niu ZX: The structure, genetic polymorphisms, expression and biological functions of complement receptor type 1 (CR1/CD35). Immunopharmacol Immunotoxicol 2009, 31:524-535.

4. Ahearn JM, Fearon DT: Structure and function of the complement receptors, CR1 (CD35) and CR2 (CD21). Adv Immunol 1989, 46:183-219.

5. Tas SW, Klickstein LB, Barbashov SF, Nicholson-Weller A: C1q and C4b bind simultaneously to CR1 and additively support erythrocyte adhesion. J Immunol 1999, 163:5056-5063.

6. Wagner C, Ochmann C, Schoels M, Giese T, Stegmaier S, Richter R, Hug F, Hansch GM: The complement receptor 1, CR1 (CD35), mediates inhibitory signals in human T-lymphocytes. Mol Immunol 2006, 43:643-651.

7. Jozsi M, Prechl J, Bajtay Z, Erdei A: Complement receptor type 1 (CD35) mediates inhibitory signals in human B lymphocytes. J Immunol 2002, 168:2782-2788.

8. Rochowiak A, Niemir Zl: The structure and role of CR1 complement receptor in physiology. Pol Merkur Lekarski 2010, 28:79-83.

9. Ross GD, Lambris JD, Cain JA, Newman SL: Generation of three different fragments of bound C3 with purified factor I or serum. I. Requirements for factor H vs CR1 cofactor activity. J Immunol 1982, 129:2051-2060.

10. Coussens LM, Werb Z: Inflammation and cancer. Nature 2002, 420:860-867.

11. Jurianz K, Ziegler S, Garcia-Schuler H, Kraus S, Bohana-Kashtan O, Fishelson Z, Kirschfink M: Complement resistance of tumor cells: basal and induced mechanisms. Mol Immunol 1999, 36:929-939.

12. Weis JH, Morton CC, Bruns GA, Weis JJ, Klickstein LB, Wong WW, Fearon DT: A complement receptor locus: genes encoding $\mathrm{C} 3 \mathrm{~b} / \mathrm{C} 4 \mathrm{~b}$ receptor and C3d/Epstein-Barr virus receptor map to 1q32. J Immunol 1987, 138:312-315.

13. Wilson JG, Wong WW, Murphy EE 3rd, Schur PH, Fearon DT: Deficiency of the $\mathrm{C} 3 \mathrm{~b} / \mathrm{C} 4 \mathrm{~b}$ receptor (CR1) of erythrocytes in systemic lupus erythematosus: analysis of the stability of the defect and of a restriction fragment length polymorphism of the CR1 gene. J Immunol 1987, 138:2708-2710.

14. Xiang L, Rundles JR, Hamilton DR, Wilson JG: Quantitative alleles of CR1: coding sequence analysis and comparison of haplotypes in two ethnic groups. J Immunol 1999, 163:4939-4945.

15. Birmingham DJ, Chen W, Liang G, Schmitt HC, Gavit K, Nagaraja HN: A CR1 polymorphism associated with constitutive erythrocyte CR1 levels affects binding to C4b but not C3b. Immunology 2003, 108:531-538.

16. Holers VM, Chaplin DD, Leykam JF, Gruner BA, Kumar V, Atkinson JP: Human complement $\mathrm{C} 3 \mathrm{~b} / \mathrm{C} 4 \mathrm{~b}$ receptor (CR1) mRNA polymorphism that 
correlates with the CR1 allelic molecular weight polymorphism. Proc Natl Acad Sci U S A 1987, 84:2459-2463.

17. Zhang Q, Yu JT, Zhu QX, Zhang W, Wu ZC, Miao D, Tan L: Complement receptor 1 polymorphisms and risk of late-onset Alzheimer's disease. Brain Res 2010, 1348:216-221

18. He JR, Xi J, Ren ZF, Qin H, Zhang Y, Zeng YX, Mo HY, Jia WH: Complement receptor 1 expression in peripheral blood mononuclear cells and the association with clinicopathological features and prognosis of nasopharyngeal carcinoma. Asian Pac J Cancer Prev 2012, 13:6527-6531.

19. Srivastava A, Mittal B: Complement receptor 1 (A3650G Rsal and intron 27 HindIII) polymorphisms and risk of gallbladder cancer in north Indian population. Scand J Immunol 2009, 70:614-620.

20. Ferreira CG: Lung cancer in developing countries. Am Soc Clin Oncol Educ Book 2013:327-331. PMID:23714537.

21. Amos Cl, Wu X, Broderick P, Gorlov IP, Gu J, Eisen T, Dong Q, Zhang Q, Gu X, Vijayakrishnan J, Sullivan K, Matakidou A, Wang Y, Mills G, Doheny K, Tsai YY, Chen WV, Shete S, Spitz MR, Houlston RS: Genome-wide association scan of tag SNPs identifies a susceptibility locus for lung cancer at 15q25.1. Nat Genet 2008, 40:616-622.

22. Hung RJ, McKay JD, Gaborieau V, Boffetta P, Hashibe M, Zaridze D, Mukeria A, Szeszenia-Dabrowska N, Lissowska J, Rudnai P, Fabianova E, Mates D, Bencko V, Foretova L, Janout V, Chen C, Goodman G, Field JK, Liloglou T, Xinarianos G, Cassidy A, McLaughlin J, Liu G, Narod S, Krokan HE, Skorpen F, Elvestad MB, Hveem K, Vatten L, Linseisen J, et al: A susceptibility locus for lung cancer maps to nicotinic acetylcholine receptor subunit genes on $15 q 25$. Nature 2008, 452:633-637

23. Wang Y, Broderick P, Webb E, Wu X, Vijayakrishnan J, Matakidou A, Qureshi M, Dong Q, Gu X, Chen WW, Spitz MR, Eisen T, Amos Cl, Houlston RS: Common 5 p15.33 and 6p21.33 variants influence lung cancer risk. Nat Genet 2008 40:1407-1409.

24. McKay JD, Hung RJ, Gaborieau V, Boffetta P, Chabrier A, Byrnes G, Zaridze D, Mukeria A, Szeszenia-Dabrowska N, Lissowska J, Rudnai P, Fabianova E, Mates D, Bencko V, Foretova L, Janout V, McLaughlin J, Shepherd F, Montpetit A, Narod S, Krokan HE, Skorpen F, Elvestad MB, Vatten L, Njølstad I, Axelsson T, Chen C, Goodman G, Barnett M, Loomis MM, et al: Lung cancer susceptibility locus at 5p15.33. Nat Genet 2008, 40:1404-1406.

25. Markiewski MM, Lambris JD: The role of complement in inflammatory diseases from behind the scenes into the spotlight. Am J Pathol 2007, 171:715-727.

26. Ricklin D, Lambris JD: Complement-targeted therapeutics. Nat Biotechnol 2007, 25:1265-1275.

27. Hugli TE: Biochemistry and biology of anaphylatoxins. Complement 1986 , 3:111-127.

28. Ostrand-Rosenberg S: Cancer and complement. Nat Biotechnol 2008, 26:1348-1349.

29. Markiewski MM, DeAngelis RA, Benencia F, Ricklin-Lichtsteiner SK, Koutoulaki A, Gerard C, Coukos G, Lambris JD: Modulation of the antitumor immune response by complement. Nat Immuno/ 2008, 9:1225-1235.

30. Markiewski MM, Lambris JD: Is complement good or bad for cancer patients? A new perspective on an old dilemma. Trends Immunol 2009, 30:286-292.

31. Fan $Q$, He JF, Wang QR, Cai HB, Sun XG, Zhou XX, Qin HD, Shugart $Y Y$, Jia WH: Functional polymorphism in the 5'-UTR of CR2 is associated with susceptibility to nasopharyngeal carcinoma. Oncol Rep 2013, 30:11-16.

32. Cerhan JR, Novak AJ, Fredericksen ZS, Wang AH, Liebow M, Call TG, Dogan A, Witzig TE, Ansell SM, Habermann TM, Kay NE, Slager SL: Risk of non-Hodgkin lymphoma in association with germline variation in complement genes. Br J Haematol 2009, 145:614-623.

33. Zhang Z, Yu D, Yuan J, Guo Y, Wang H, Zhang X: Cigarette smoking strongly modifies the association of complement factor $\mathrm{H}$ variant and the risk of lung cancer. Cancer Epidemiol 2012, 36:e111-e115.

34. Shen M, Vermeulen R, Rajaraman P, Menashe I, He X, Chapman RS, Yeager M, Thomas G, Burdett L, Hutchinson A, Yuenger J, Chanock S, Lan Q: Polymorphisms in innate immunity genes and lung cancer risk in Xuanwei, China. Environ Mol Mutagen 2009, 50:285-290.

35. Fearon DT: Identification of the membrane glycoprotein that is the $\mathrm{C} 3 \mathrm{~b}$ receptor of the human erythrocyte, polymorphonuclear leukocyte, B lymphocyte, and monocyte. J Exp Med 1980, 152:20-30.

36. Besaratinia A, Pfeifer GP: Second-hand smoke and human lung cancer. Lancet Oncol 2008, 9:657-666.
37. Coyle YM, Minahjuddin AT, Hynan LS, Minna JD: An ecological study of the association of metal air pollutants with lung cancer incidence in Texas. J Thorac Oncol 2006, 1:654-661

38. Garshick E, Laden F, Hart JE, Rosner B, Smith TJ, Dockery DW, Speizer FE: Lung cancer in railroad workers exposed to diesel exhaust. Environ Health Perspect 2004, 112:1539-1543.

39. Brennan P, Buffler PA, Reynolds P, Wu AH, Wichmann HE, Agudo A, Pershagen G, Jockel KH, Benhamou S, Greenberg RS, Merletti F, Winck C, Fontham ET, Kreuzer M, Darby SC, Forastiere F, Simonato L, Boffetta P. Secondhand smoke exposure in adulthood and risk of lung cancer among never smokers: a pooled analysis of two large studies. Int J Cancer 2004, 109:125-131.

40. Lee G, Walser TC, Dubinett SM: Chronic inflammation, chronic obstructive pulmonary disease, and lung cancer. Curr Opin Pulm Med 2009, 15:303-307.

41. Engels EA: Inflammation in the development of lung cancer: epidemiological evidence. Expert Rev Anticancer Ther 2008, 8:605-615.

42. Kullo IJ, Ding K, Shameer K, McCarty CA, Jarvik GP, Denny JC, Ritchie MD, Ye Z, Crosslin DR, Chisholm RL, Manolio TA, Chute CG: Complement receptor 1 gene variants are associated with erythrocyte sedimentation rate. Am J Hum Genet 2011, 89:131-138.

43. Teeranaipong $P$, Ohashi J, Patarapotikul J, Kimura R, Nuchnoi $P$, Hananantachai H, Naka I, Putaporntip C, Jongwutiwes S, Tokunaga K: A functional single-nucleotide polymorphism in the CR1 promoter region contributes to protection against cerebral malaria. J Infect Dis 2008, 198:1880-1891.

44. Chen GB, Xu Y, Xu HM, Li MD, Zhu J, Lou XY: Practical and theoretical considerations in study design for detecting gene-gene interactions using MDR and GMDR approaches. PLoS One 2011, 6:e16981.

45. Lou XY, Chen GB, Yan L, Ma JZ, Zhu J, Elston RC, Li MD: A generalized combinatorial approach for detecting gene-by-gene and gene-by-environment interactions with application to nicotine dependence. Am J Hum Genet 2007, 80:1125-1137.

doi:10.1186/1476-4598-13-56

Cite this article as: Yu et al:: Tag SNPs in complement receptor-1 contribute to the susceptibility to non-small cell lung cancer. Molecular Cancer 2014 13:56

\section{Submit your next manuscript to BioMed Central and take full advantage of:}

- Convenient online submission

- Thorough peer review

- No space constraints or color figure charges

- Immediate publication on acceptance

- Inclusion in PubMed, CAS, Scopus and Google Scholar

- Research which is freely available for redistribution 